\title{
The Protective Effect of Clostridium novyi Type B Alpha-Toxoid against Challenge with Spores in Guinea Pigs
}

\author{
Katsuhiko AMIMOTO, Osamu SASAKI, Makoto ISOGAI, Takashi KITAJIMA, Eiji OISHI, Nobutaka OKADA and \\ Hisao YASUHARA \\ Division of Veterinary Microbiology, Kyoto Biken Laboratories, 24-16 Makisima-cho, Uji, Kyoto 611-0041, Japan
}

(Received 6 August 1997/Accepted 24 December 1997) ABSTRACT. Clostridium novyi $($ C. novyi) Type B alpha-toxin was purified from culture supernatant by column chromatography, and was
inactivated by formalin. A purified alpha-toxoid vaccine was prepared by mixing it with an aluminum phosphate gel adjuvant. Guinea
pigs immunized twice with $4 \mu \mathrm{g}$ or more of alpha-toxin survived against challenge with $C$. novyi Type B spores. Anti-alpha-toxin
(antitoxin) titer was measured by toxin neutralization test using Vero cells. All of the guinea pigs having antitoxin titers of 10 units (U) or
more at challenge were survived. In another experiment, guinea pigs were immunized with crude alpha-toxoid vaccines prepared by
inactivated culture supernatant or by adding broken bacterial cells to the former. In this experiment, $10 \mathrm{U}$ of antitoxin titer was the border
of survival or death after challenge. Guinea pigs with antitoxin titers of less than $5 \mathrm{U}, 5 \mathrm{U}$ and $10 \mathrm{U}$ died at 2,3 to 4 and 4 days,
respectively, after challenge. These results suggest that $C$. novyi alpha-toxin was the main protective antigen against challenge exposure
to spores in guinea pigs. - KEY wORDS: alpha-toxin, Clostridium novyi, protective effect, toxoid.

Clostridium novyi (C. novyi) causes gas gangrene and black disease in cattle, sheep and other animals [4]. $C$. novyi Type B produces several extracellular toxins including alpha-toxin which has lethal, edematizing and cytotoxic activities $[2-4,9,17,18]$. The diseases associated with $C$. novyi have been controlled using toxoid vaccines and toxoid and bacterial vaccines [4]. Inactivated alpha-toxin in these vaccines is regarded as the major protective antigen of $C$. novyi [4]. However, there have been no reports concerning the effects of purified alpha-toxin. Therefore, protection tests with the purified alpha-toxin should be performed.

Toxin neutralization tests have been used to determine the potencies of clostridial vaccines including $C$. novyi vaccines [8]. The current method used for neutralization testing is an in vivo assay using large numbers of animals, and the results are often unreliable. Recently, titrations of clostridial toxins and antitoxins were investigated in cell culture $[2,3,5-7,10,13,15-17,19,22]$, and there were reports that $C$. novyi alpha-toxin showed cytotoxicity to porcine endothelial and chicken embryonic fibroblasts (CEF) [3, 17], Vero and CHO cells [2].

In this study, we examined the protective effects of purified $C$. novyi alpha-toxoid against lethal dose challenge exposure to $C$. novyi spores in guinea pigs. In addition, we measured anti-alpha-toxin (antitoxin) titers of guinea pigs immunized with $C$. novyi alpha-toxoid using Vero cells, and examined the relationship between the antitoxin titer and the protective effect.

\section{MATERIALS AND METHODS}

Bacterial strain: Strain CN1025 of C. novyi Type B obtained from the National Institute of Health, Tokyo, Japan, was used in this study.
Purification of alpha-toxin: Alpha-toxin was purified as described by Pietrzykowski et al. [18] with slight modifications. The strain CN1025 was cultured in heart infusion broth (Nissui, Tokyo, Japan) containing $0.5 \%$ glucose and $0.05 \%$ L-cysteine hydrochloride adjusted to $\mathrm{pH}$ 7.5. The culture fluid was centrifuged, and the supernatant was filtered through a membrane with $0.2 \mu \mathrm{m}$ pore size (Japan Pall, Tokyo, Japan). The supernatant was concentrated by ultrafiltration using Labo module AHP-1010 (50 kDa cut-off: Asahikasei, Tokyo, Japan). Alpha-toxin was purified by high performance liquid chromatography (HPLC) using a Phenyl-5PW column (Tosoh, Tokyo, Japan) and a DEAE-5PW anion exchange column (Tosoh, Tokyo, Japan). Fractions of HPLC containing alpha-toxin were detected using mouse lethality test, cytotoxicity in Vero cells and sodium dodecyl sulfate-polyacrylamide gel electrophoresis (SDS-PAGE) as described elsewhere [11], and the positive fractions were pooled. Protein contents were estimated by the method of Lowry et al. [12]. Purified alpha-toxin was inactivated by adding formalin at a final concentration of $0.4 \mathrm{v} / \mathrm{v} \%$ at $37^{\circ} \mathrm{C}$ for $24 \mathrm{hr}$.

Preparation of crude alpha-toxin and broken bacterial cells: The actively growing cells were cultured in CLB broth [1] containing chopped beef liver at $37^{\circ} \mathrm{C}$ for $18 \mathrm{hr}$. The culture fluid was separated from the bacterial cells by centrifugation at 7,000 $\times \mathrm{g}$ for $30 \mathrm{~min}$. The supernatant was designated crude alpha-toxin. Formalin was added to the crude alpha-toxin at a final concentration of $0.4 \mathrm{v} / \mathrm{v} \%$, which was then incubated at $37^{\circ} \mathrm{C}$ for 3 days to inactivate alpha-toxin and small residual bacterial cells. The inactivated crude alpha-toxin was concentrated to $1 / 10$ of the original volume by ultrafiltration using Labo module ACP-1010 (13 kDa cut-off: Asahikasei, Tokyo, Japan). The bacterial cells were suspended in $0.15 \mathrm{M}$ phosphate buffered 
saline (PBS, pH 7.2) at $1 / 25$ of the original volume, and were washed 3 times with PBS. The bacterial cells were inactivated with formalin at a final concentration of $0.4 \mathrm{v} / \mathrm{v}$ $\%$ at $37^{\circ} \mathrm{C}$ for 3 days, and were then broken with a Dinomill blender Type KDL (WILLY A. BACHFEN AG, Basel, Switzerland) at 2,000 rpm for $4 \mathrm{hr}$.

Vaccine preparation: The purified alpha-toxoid was diluted to final concentrations of $0.25,1,4$ and $16 \mu \mathrm{g} / 0.32$ $\mathrm{m} l$ with PBS. Each of the diluted alpha-toxoid preparations was mixed with aluminum phosphate gel (APG) adjuvant to a final concentration of $20 \mathrm{v} / \mathrm{v} \%$. The crude alpha-toxoid and the broken bacterial cells were diluted as shown in Table 1 with PBS, and APG adjuvant was added to a final concentration of $20 \mathrm{v} / \mathrm{v} \%$.

Protection test: Five Hartley guinea pigs (female, 4 weeks old) were immunized twice intramuscularly with $0.4 \mathrm{ml}$ of prepared vaccines at 2 -week intervals. Ten days after the final immunization, all guinea pigs were challenged intramuscularly with 10 minimum lethal dose (MLD) $(1.2 \times$ $10^{3}$ most probable number) of strain $\mathrm{CN} 1025$ spores suspended in $0.5 \mathrm{ml}$ of $3 \% \mathrm{CaCl}_{2} \cdot 2 \mathrm{H}_{2} \mathrm{O}$ solution. These guinea pigs were observed daily for 7 days after challenge. Blood samples were collected from the immunized guinea pigs before the challenge.

Immunoblotting procedure: The purified alpha-toxin (1 $\mu \mathrm{g}$ of protein) were electrophoresed by SDS-PAGE, and were transferred electrophoretically from the gel to an Immobilon membrane (Milipore, Bedford, MA, U.S.A.) by the method of Towbin et al. [21]. The membrane was incubated with PBS containing $3 \%$ bovine serum albumin at $37^{\circ} \mathrm{C}$ for $1 \mathrm{hr}$, and was then incubated with 1:50 diluted guinea pig sera (antitoxin titers of $10 \mathrm{U}$ ) at room temperature for $30 \mathrm{~min}$. After washing, the membrane was incubated with 1:200 diluted horseradish peroxidase-conjugated antiguinea pig Ig-G (CAPPEL, U.S.A.). The reactivity was visualized with $50 \mathrm{mM}$ Tris- $\mathrm{HCl}$ buffer, $\mathrm{pH} 8.0$ containing $0.05 \%$ 3-3'-diaminobenzidine (Dojin Lab., Kumamoto, Japan) and $0.02 \% \mathrm{H}_{2} \mathrm{O}_{2}$.

Determination of cytotoxic activity and measurement of antitoxin titer: Vero cells were grown in Eagle's minimal essential medium (Nissui, Tokyo, Japan) containing 5\% fetal calf serum. The same medium was used as the diluent in tests for showing high cytotoxicity. Vero cells were suspended at $2 \times 10^{4}$ cells $/ 0.1 \mathrm{~m} l$ of medium and dispensed into 96 -well micro test plates, followed by incubation at $37^{\circ} \mathrm{C}$ for $24 \mathrm{hr}$ under $5 \% \mathrm{CO}_{2}$. The cytotoxicity assays were performed as follows. A $0.1 \mathrm{ml}$ aliquot of two-fold serial diluted alpha-toxins was dispensed into each cell culture well without growth media. Then, the cells were incubated at $37^{\circ} \mathrm{C}$ for $48 \mathrm{hr}$ under $5 \% \mathrm{CO}_{2}$. The surviving cells were detected by 3-(4,5-dimethyl-2-thiazolyl)-2,5diphenyl-2H tetrazolium bromide (MTT) assay [14], the color of which measured by enzymes in a microplate reader. The reciprocal of the highest dilution of alpha-toxin which showed under $50 \%$ of optical density against the control well without alpha-toxin was considered as one cytotoxic unit (CU). The antitoxin titers were measured by
Table 1. Constitution of crude alpha-toxoid vaccines

\begin{tabular}{|c|c|c|c|c|}
\hline \multirow[t]{2}{*}{ Group } & \multirow{2}{*}{$\begin{array}{c}\text { Culture } \\
\text { No. }\end{array}$} & \multicolumn{2}{|c|}{ Supernatant } & \multirow{2}{*}{ 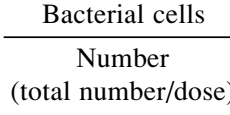 } \\
\hline & & $\begin{array}{c}\text { Cytotoxic activity } \\
(\mathrm{CU} / \mathrm{m} l)\end{array}$ & $\begin{array}{l}\text { Volume } \\
\text { (ml/dose) }\end{array}$ & \\
\hline A & & & $0.05^{\mathrm{b})}$ & None $^{\mathrm{c})}$ \\
\hline B & 1 & $32,000^{\mathrm{a})}$ & 0.10 & None \\
\hline $\mathrm{C}$ & & & 0.10 & $1 \times 10^{8 \mathrm{~d})}$ \\
\hline D & & & 0.05 & None \\
\hline $\mathrm{E}$ & 2 & 64,000 & 0.10 & None \\
\hline $\mathrm{F}$ & & & 0.10 & $1 \times 10^{8}$ \\
\hline
\end{tabular}

a) Cytotoxic activity of the supernatant fluid after concentration using Vero cells. b) Concentrated to $1 / 10$ of the original volume by ultrafiltration. c) No broken bacterial cells. d) Total bacterial cell humber before breaking with a Dinomill blender.

neutralization tests in Vero cells. A mixture of an equal volume of two fold serial dilutions of serum and $10 \mathrm{CU}$ of crude alpha-toxin was incubated at $37^{\circ} \mathrm{C}$ for $1 \mathrm{hr}$ under $5 \%$ $\mathrm{CO}_{2}$. A $0.1-\mathrm{m} l$ aliquot of each mixture was dispensed into wells without growth media, and the cell cultures were incubated at $37^{\circ} \mathrm{C}$ for 2 days under $5 \% \mathrm{CO}_{2}$. Antitoxin titers, shown in units (U), were expressed as the reciprocal of the highest dilution showing over $50 \%$ of optical density against the control well by MTT assay. One international unit $/ \mathrm{m} l$ of standard $C$. novyi antitoxin obtained from National Institute of Health (Tokyo, Japan) was measured as $250 \mathrm{U}$ by this method.

Determination of lethality: A $0.5 \mathrm{~m} l$ aliquot of two fold serially diluted alpha-toxin was intraperitoneally injected into $5 \mathrm{ddY}$ or BALB/c male mice (about $20 \mathrm{~g}$ ) at each dilution. The MLD was defined as the highest dilution that killed $100 \%$ of the mice within 3 days.

Detection of lecithinase and hemolytic activity: Detection of lecithinase and hemolytic activity was performed by the method of Richard et al. [20] except that $1 \mathrm{v} / \mathrm{v} \%$ mouse blood cells were used in the hemolytic assay.

\section{RESULTS}

The specific activities of alpha-toxin, assayed in both Vero cells and mice, increased during purification (Table 2). In Vero cells, the specific activity of purified alphatoxin showed $6,250,000 \mathrm{CU} / \mathrm{mg}$ and the cytotoxic activity was increased about 755 -fold after purification. A minimum tissue culture dose (MTCD), which was calculated from specific activity, was about $1.6 \mathrm{ng}$ of the purified alphatoxin. In mice, the specific activity of the purified alpha-toxin showed 7,820 MLD/mg, and the lethal activity increased by about 189 -fold after purification. The specific activity was the same in both ddY and BALB/c mice. The MLD, which was calculated from the specific activity, was about $128 \mathrm{ng}$ of the purified alpha-toxin. The increases in specific activity differed between the assays with Vero cells and mice. The lecithinase and hemolytic activity of the purified alpha-toxin were measured. Both of these activities 
Table 2. Specific activity during alpha-toxin purification steps

\begin{tabular}{|c|c|c|c|c|c|c|}
\hline \multirow[t]{2}{*}{ Step } & \multirow{2}{*}{$\begin{array}{l}\text { Volume } \\
\qquad(\mathrm{m} l)\end{array}$} & \multirow{2}{*}{$\begin{array}{c}\text { Protein } \\
\text { concentration } \\
(\mathrm{mg} / \mathrm{m} l)\end{array}$} & \multicolumn{2}{|c|}{ Vero cells } & \multicolumn{2}{|c|}{ Mice } \\
\hline & & & $\begin{array}{c}\text { Cytotoxic activity } \\
(\mathrm{CU} / \mathrm{m} l)\end{array}$ & $\begin{array}{c}\text { Specific activity } \\
(\mathrm{CU} / \mathrm{mg})\end{array}$ & $\begin{array}{l}\text { Lethal activity } \\
(\mathrm{MLD} / \mathrm{m} l)\end{array}$ & $\begin{array}{l}\text { Specific activity } \\
\text { (MLD/mg) }\end{array}$ \\
\hline Culture supernatant & 8,000 & 7.73 & 64,000 & $8,280^{\mathrm{a})}$ & 320 & $41.4^{\mathrm{b})}$ \\
\hline Concentrate & 350 & 11.54 & $2,048,000$ & 177,500 & 5,120 & 444 \\
\hline Phenyl-5PW & 300 & 0.131 & 512,000 & $3,908,000$ & 640 & 4,890 \\
\hline DEAE-5PW & 40 & 0.665 & $4,096,000$ & $6,250,000$ & 5,120 & 7,820 \\
\hline
\end{tabular}

a) The specific activity was shown according to the formula: cytotoxic activity $(\mathrm{CU} / \mathrm{m} l) /$ protein $(\mathrm{mg} / \mathrm{ml})$. b) The specific activity was shown according to the formula: lethal activity $(\mathrm{MLD} / \mathrm{m} l) /$ protein $(\mathrm{mg} / \mathrm{ml})$.

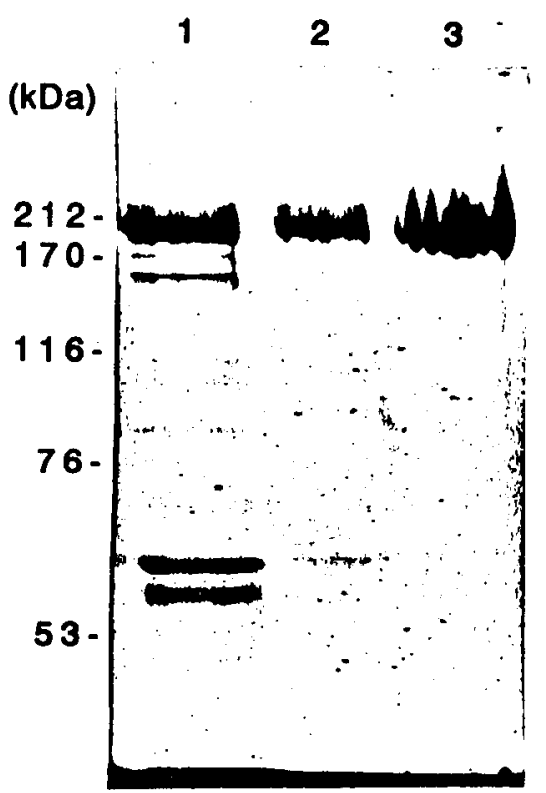

Fig. 1. SDS-PAGE (7.5\% Gel) of isolated alpha-toxin fractions with HPLC. Lane: 1, Concentrated culture supernatant; Lane: 2, Protein eluted with $100 \mathrm{mM}$ sodium phosphate buffer from Phenyl-5PW; Lane: 3, Pooled active fractions obtained from DEAE5PW (Purified alpha-toxin).

of the purified alpha-toxin $(66.5 \mu \mathrm{g}$ of protein) were less than 2-fold. In addition, the purification of alpha-toxin was determined by SDS-PAGE. The results of SDS-PAGE of concentrated culture supernatant, proteins eluted from Phenyl-5PW and DEAE-5PW fractions, are shown in Fig. 1. The concentrated culture supernatant showed major band at $200 \mathrm{kDa}$ and minor bands at about 160, 60 and $55 \mathrm{kDa}$ of protein in SDS-PAGE. The proteins eluted from Phenyl$5 \mathrm{PW}$ showed only traces of $60 \mathrm{kDa}$ protein with a major band at $200 \mathrm{kDa}$ of protein. The purified alpha-toxin, eluted from DEAE-5PW fractions, showed a single band, the molecular weight of which was about $200 \mathrm{kDa}$.

Guinea pigs immunized with vaccines containing the purified alpha-toxin of $4 \mu \mathrm{g}$ or more survived but those treated with $1 \mu \mathrm{g}$ or less died after challenge. The antitoxin titers of all surviving guinea pigs were $10 \mathrm{U}$ or more, while

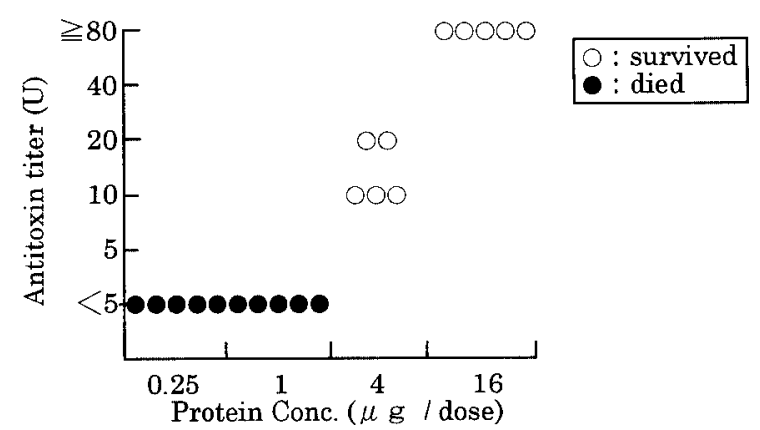

Fig. 2. Relationship between immunized protein concentration, antitoxin titer before challenge and challenge results in guinea pigs immunized with purified alpha-toxoid vaccines. The guinea pigs were observed for 7 days after challenge.

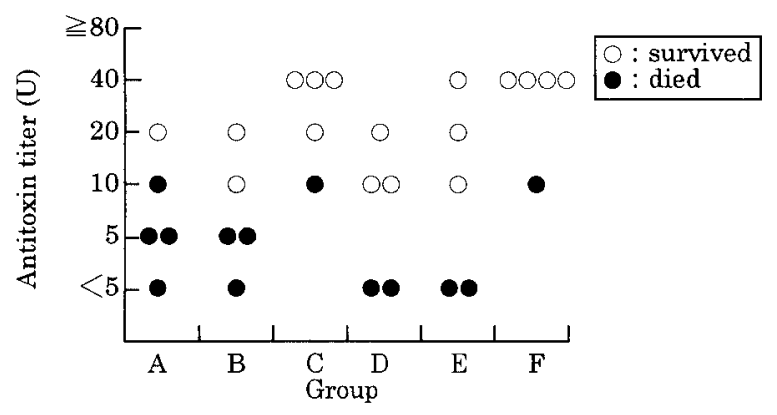

Fig. 3. Relationship between antitoxin titer before challenge and challenge results in guinea pigs immunized with crude alpha-toxoid vaccines. The guinea pigs were observed for 7 days after challenge. Preparation of crude alpha-toxoid vaccines is shown in Table 1.

those of all dead guinea pigs were under $5 \mathrm{U}$ (Fig. 2). In guinea pigs immunized with the crude alpha-toxoid vaccines, the relationships between the antitoxin titers before challenge and survival or death after the challenge are shown in Fig. 3. In all groups, guinea pigs with an antitoxin titer of $20 \mathrm{U}$ or more survived, while those with titers of $5 \mathrm{U}$ or less died. Guinea pigs with a titer of $10 \mathrm{U}$ existed on the border of survival and death. Guinea pigs immunized with crude alpha-toxoid vaccines containing broken bacterial cells (group $\mathrm{C}$ and $\mathrm{F}$ ) showed the same relationship between the antitoxin titers and challenge results as the result of the purified alpha-toxoid vaccine. Antitoxin titers of group $\mathrm{C}$ 


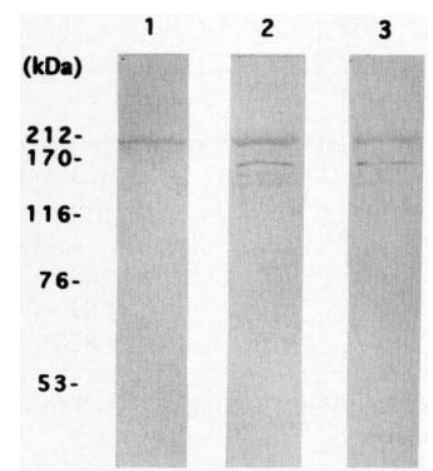

Fig. 4. Immunoblotting of guinea pig sera reacted with purified alpha-toxin. Lane: 1 , The serum was obtained from guinea pig immunized with purified alpha-toxoid vaccine; Lane: 2 , The serum was obtained from guinea pig immunized with crude alpha-toxoid vaccine without broken bacterial cells; Lane: 3, The serum was obtained from guinea pig immunized with crude alpha-toxoid vaccine with broken bacterial cells; The antitoxin titers of all guinea pig sera is $10 \mathrm{U}$.

were higher than those of group B which were immunized with the crude alpha-toxoid vaccines without broken bacterial cells. This result was recognized as statistically significant by Student's $t$-test. Although, the antitoxin titers of group $\mathrm{F}$ were not recognized as significantly different from those of group E by Student's $t$-test. Guinea pigs with antitoxin titers of under $5 \mathrm{U}, 5 \mathrm{U}$ and $10 \mathrm{U}$ died at 2 days, 3 to 4 days and 4 days after challenge, respectively. Also, guinea pigs immunized with the crude alpha-toxoid vaccine without broken bacterial cells (group A) and with that containing broken bacterial cells (group C and F) showed the same prolongation of survival. Antisera, which showed $10 \mathrm{U}$, were analyzed with immunoblotting. The antiserum of the guinea pig immunized with purified alpha-toxoid vaccine reacted only with the $200 \mathrm{kDa}$ protein in immunoblotting. The antisera of the guinea pig immunized with crude alpha-toxoid vaccines reacted mainly with the $200 \mathrm{kDa}$ protein and also reacted weakly with four proteins of about 160 to $90 \mathrm{kDa}$ in immunoblotting (Fig. 4).

\section{DISCUSSION}

There have been many reports of the biological activities of alpha-toxin. In Vero cells, Ball et al. [2] reported that the MTCD of purified alpha-toxin was $0.1 \mathrm{ng}$ of protein. In mice, Bette et al. [3] reported that a $\mathrm{LD}_{50}$ of purified alphatoxin was $200 \mathrm{ng} / \mathrm{kg}$ of body weight in mice, and the $\mathrm{LD}_{50}$ of that calculated from the report of Izumi et al. [9] was about $2.5 \mathrm{ng}$ of protein. Pietrzykowski et al. [18] reported that the MLD of purified alpha-toxin was $4 \mathrm{ng}$ of protein, and Ball et al. [2] reported that the MLD of purified alphatoxin was 5 to $10 \mathrm{ng}$ of protein. In our results, the MTCD of the purified alpha-toxin was $1.6 \mathrm{ng}$ of protein in Vero cells and the MLD was $128 \mathrm{ng}$ of protein in mice. The activity results of our purified alpha-toxin were lower than those reported in both in vivo and in vitro assays. Generally, the differences between those reports and our results could be due to differences in the cell lines and mouse strains used, although, those used by Ball et al., Vero cells and $\mathrm{BALB} / \mathrm{c}$ mice, were the same as in our study. Another possible reason is that the differences may be due to fall of activities for the purification, since in the biological activities of our purified alpha-toxin, the ratio of MLD to $\mathrm{CU}$ of alpha-toxin was as follows: $1 \mathrm{MLD}=20 \mathrm{CU}$ at the culture supernatant step and $1 \mathrm{MLD}=800 \mathrm{CU}$ at the DEAE5PW step. Izumi et al. [9] reported that the ratio of 50\% lethal dose $\left(\mathrm{LD}_{50}\right)$ to $50 \%$ edematizing dose $\left(\mathrm{OED}_{50}\right)$ of the purified alpha-toxin was as follows: $1 \mathrm{LD}_{50}=10 \mathrm{OED}_{50}$ which was the same as those of crude and partially purified alpha-toxin in their assays. We suggest that the active segment for cytotoxicity is different from that for lethality and edematization, and the lethal and the edematizing response in mice is more complicated than the cytotoxic response in Vero cells. Also, Ball et al. [2] and Izumi et al. [9] reported that alpha-toxin did not show lecithinase and hemolytic activities, these results were the same as in our results. The molecular weight of alpha-toxin has been reported by several researchers. Izumi et al. [9] reported that the molecular weight of alpha-toxin was determined as 260-280 kDa by tube gel SDS-PAGE and gel filtration. Pietrzykowski et al. [18] and Ball et al. [2] reported that the molecular weight of alpha-toxin was $200 \mathrm{kDa}$ as determined by slab gel SDS-PAGE. Pietrzykowski et al. [18] suggested that this difference in molecular weight may have been due to the measurement method used. In our study, purified alpha-toxin was had an apparent molecular weight of 200 $\mathrm{kDa}$ as determined by slab gel SDS-PAGE. From the results of biological activities and the molecular weight, it was concluded that the purified alpha-toxin used in our study was $C$. novyi alpha-toxin.

For the toxin neutralization test used to determine the potency of $C$. novyi vaccines, alpha-toxin is neutralized with the sera from vaccinated animals and injected into mice. The indicator of neutralization is lethality in mice [8]. Knight et al. [10] reported that the neutralization test of $C$. septicum alpha-toxin using Vero cells was a useful method for measurement of antitoxin titers of sera in vaccine field trials and vaccine potency tests. In vitro assays are superior to in vivo assay in that they do not require use of large numbers of mice and the results are more reliable. For the measurement of antitoxin titer, Bette et al. [3] reported that C. novyi alpha-toxin showed high cytotoxicity in some kinds of primary cells such as endothelial cells from porcine pulmonary arteries and chicken embryos fibroblast, and Oksche et al. [17] used porcine endothelial cells in an in vitro study. Ball et al. [2] reported that Vero cells showed high susceptibility to $C$. novyi alpha-toxin. Vero cells, 
which are permanent cells, are used by many researchers of clostridial cytotoxin $[10,16,19,22]$. We decided that Vero cells would be used as the measurement of antitoxin titer. In our study, we performed toxin neutralization tests in Vero cells, and the results were reflected in the challenge test. Thus, toxin neutralization tests using Vero cells can be used for vaccine field trials in place of vaccine potency tests using laboratory animals.

We investigated the protective effect of alpha-toxoid with the purified alpha-toxoid vaccine and the toxin neutralization test. We found that the antitoxin titer of $10 \mathrm{U}$ was necessary for protection, and the $4 \mu \mathrm{g}$ of purified alpha-toxin was needed to provide a sufficient antitoxin titer in guinea pigs. Also, guinea pigs immunized with the crude alpha-toxoid vaccines had antitoxin titers of $10 \mathrm{U}$ and showed a high survival rate. In immunoblotting, antisera reacted not only with alpha-toxin, but also with several other proteins. We suggest that the antibodies, which were produced from influential antigenic protein in crude alpha-toxoid vaccines, reacted with small residual other proteins in the purified alpha-toxin. Although, those antibodies have no relation to the protective effect. The antitoxin titers of the guinea pigs in group $\mathrm{C}$ were higher than those of group $\mathrm{B}$. This might have been due to protoxin included in bacterial cells or broken bacterial cells acting as a carrier protein. Moreover, the number of days until death after challenge was related to the antitoxin titer in guinea pigs. In these results, we identified that alpha-toxin was the main protective antigen against challenge exposure with $C$. novyi type B spores in guinea pigs.

\section{REFERENCES}

1. Azeti, H., Seto, K., Mukawa, Y. and Suzuki, K. 1962. Studies on the potency test of black leg vaccine. Jpn. J. Vet. Sci. 24: 267-275 (in Japanese with English summary).

2. Ball, D. W., Tassell, R. L. V., Roberts, M. D., Hahn, P. E., Lyerly, D. M. and Wilkins, T. D. 1993. Purification and characterization of alpha-toxin produced by Clostridium novyi type A. Infect. Immun. 61: 2912-2918.

3. Bette, P., Frevert, J., Mauler, F., Suttorp, N. and Habermann, E. 1989. Pharmacological and biochemical studies of cytotoxicity of Clostridium novyi type A alpha-toxin. Infect. Immun. 57: 2507-2513.

4. Blood, D. C. and Radostits, O. M. 1989. Veterinary Medicine, 7th ed., London.

5. Ehrich, M., Tassel, R. L., Libby, J. M. and Wilkins, T. D. 1980. Production Clostridium difficile antitoxin. Infect. Immun. 28: 1041-1043.

6. Fritz, G., Schroeder, P. and Aktories, K. 1995. Isolation and characterization of a Clostridium botulinum $\mathrm{C} 2$ toxin-resistant cell line: evidence for possible involvement of the cellular C2 II receptor in growth regulation. Infect. Immun. 63: 23342340.

7. Giry, M., Popoff, M. R., Eichel-streiber, C. and Boquet, P.
1995. Transient expression of RhoA, -B, and -C GTPases in HeLa cells potentiates resistance to Clostridium difficile toxins $\mathrm{A}$ and $\mathrm{B}$ but not to Clostridium sordellii lethal toxin. Infect. Immun. 63: 4063-4071.

8. Hogarth-Scott, R. S., Liardet, D. M. and Morris, P. J. 1980. Levamisole vaccine combinations: 1 . heightened antibody response. Aust. Vet. J. 56: 285-291.

9. Izumi, N., Kondo, H., Ohisi, I. and Sakaguti, G. 1983. Purification and characterization of $\alpha$-toxin of Clostridium oedematiens type A. Jpn. J. Med. Sci. Biol. 36: 135-145.

10. Knight, P. A., Tilleray, J. H. and Queminet, J. 1990. In vitro tests the measurement of veterinary clostridial toxins, toxoids and antitoxins: 1. Titration of Clostridium septicum toxins and antitoxins in cell culture. Biologicals 18: 181-189.

11. Laemmli, U. K. 1970. Cleavage of structural proteins during the assembly of the head of bacteriophage T4. Nature (Lond.) 227: 680-685.

12. Lowry, O. H., Rosebrough, N. J., Farr, A. L. and Randall, R. J. 1951. Protein measurement with Foline phenol reagent. $J$. Biol. Chem. 193: 265-276.

13. Martinez, R. D. and Wilkins, T. D. 1988. Purification of Clostridium sordellii haemorragic toxin and cross-reactivity with Clostridium difficile toxin A (enterotoxin). Infect. Immun. 56: 1215-1221.

14. Mosman, T. 1983. Rapid colorimetric assay for cell growth and survival: Application to proliferation and cytotoxicity assay. J. Immunol. Methods 65: 55.

15. Nakamura, S., Tanabe, S., Yamakawa, K. and Nishida, S. 1983. Cytotoxin production by Clostridium sordellii strains. Microbiol. Immunol. 27: 495-502.

16. Nakamura, S., Ogura, H., Tanaka, J., Tanabe, N., Yamakawa, K., Hatano, M. and Nishida, S. 1984. Different in susceptibility of various cell cultures to cytotoxic culture filtrates of Clostridium sordellii. Microbiol. Immunol. 28: 493-497.

17. Oksche, A., Nakov, R. and Habermann, E. 1992. Morphological and biochemical study of cytoskeletal changes in cultured cells after extracellular application of Clostridium novyi alpha-toxin. Infect. Immun. 60: 3002-3006.

18. Pietrzykowski, E., Cox, J., Zachariou, M. and Macgregor, A. 1991. Development of an enzyme immunoassay for the detection of Clostridium novyi type B alpha toxin. Biologicals 19: 293-298.

19. Popoff, M. R. 1987. Purification of Clostridium sordellii lethal toxin and cross-reactivity with Clostridium difficile cytotoxin. Infect. Immun. 55: 35-43.

20. Richard, W. T., Sophie, E. C. H., Keith, L. M., Brian, C. M., Andrew, D. S., Shuttleworth, T. R., Derek, W. A. and David, C. K. 1989. Molecular cloning and nucleotide sequence of the alpha-toxin (phospholipase C) of Clostridium perfringens. Infect. Immun. 57: 367-376.

21. Towbin, H., Staehelin, T. and Gordon, J. 1979. Electrophoretic transfer of protein from polyacrylamide gels to nitrocellulose sheets: procedure and some applications. Proc. Natl. Acad. Sci. 76: 4350-4354.

22. Yamakawa, K., Nakamura, S. and Nishida, S. 1985. Separation of two cytotoxins of Clostridium sordellii strains. Microbiol. Immunol. 29: 553-557. 